\title{
A histochemical study on the effects of photoperiod on gonadal and adrenal function in the male bank vole (Clethrionomys glareolus)
}

\author{
K. M. Tähkä \\ Division of Physiology, Department of Zoology, University of Helsinki, Arkadiankatu 7, \\ SF-00100 Helsinki 10, Finland
}

\begin{abstract}
Summary. NADH- and NADPH-diaphorases, $3 \alpha-, \Delta^{5}-3 \beta-, 11 \beta$ - and $17 \beta$-hydroxysteroid dehydrogenases (HSD) and lipids were studied histochemically in the testes and adrenals of male bank voles kept in a long (16L:8D) or a short (8L:16D) photoperiod (Groups $L$ and $S$, respectively).

At 67 days of age the Group $L$ males were heavier and had active and significantly larger testes than Group S males. The testes of Group $\mathrm{S}$ males were regressed and were also significantly smaller than those of 18-day-old animals born and reared in a 18L:6D photoperiod. Lipid droplets were detected in the Leydig cells and intratubular spaces in the testes of Group $\mathrm{L}$ animals, but were absent from those of Group S voles.

The adrenal cortex of the Group $\mathrm{L}$ animals was virtually devoid of lipids, but large lipid inclusions were present in the basal zona fasciculata of the Group S voles. In the Group $L$ testes the diaphorase activities were more intense and the difference in enzymic activity between the seminiferous epithelium and the Leydig cells was more pronounced (especially for NADH-diaphorase) than that in the testes of Group S animals. Moreover, the $3 \alpha-$ and $\Delta^{5}-3 \beta-H S D$ activities were much stronger in the testes of sexually active animals; $17 \beta$-HSD activity was present in the Leydig cells of the active testes, and absent in the regressed testes. There was no marked difference between the two groups of animals with regard to the distribution or intensity of diaphorases, $3 \alpha-$, $\Delta^{5}-3 \beta-, 11 \beta$ - or $17 \beta$-HSD in the adrenal cortex. It is concluded that a decline in steroid synthesis occurs in the testes of voles kept in a short photoperiod. The large lipid inclusions observed in the adrenal cortex of such animals suggest decreased corticosteroid synthesis and/or secretion.
\end{abstract}

\section{Introduction}

Short photoperiods are known to have an inhibitory effect on the gonadal function of many seasonally breeding rodents, e.g. field vole (Clarke \& Forsyth, 1964; Clarke \& Kennedy, 1967; Breed \& Clarke, 1970), common vole (Lecyk, 1962; Martinet, 1963; Thibault et al., 1966), golden hamster (Hoffman \& Reiter, 1965; Berndtson \& Desjardins, 1974; Turek, Elliot, Alvis \& Menaker, 1975), Djungarian hamster (Hoffman, 1973) and grasshopper mouse (McCarthy, 1975). In many cases, the inhibitory effect of a short photoperiod has been shown to be mediated by the pineal gland (Hoffman \& Reiter 1965; Reiter, 1969, 1973; Herbert, 1971; Clarke \& Farrar, 1975; Charlton, Grocock \& Ostberg, 1976). Furthermore, a functional relationship between the pineal and adrenal glands has been suggested (Kitay \& Altschule, 1954; Kinson, Wahid \& Singer, 1967; Kinson, Singer \& Grant, 1968; Vaughan, Vaughan, Reiter \& Benson, 1972), although the zonation and function of the adrenal cortex is partly dependent on sex and functional status of the gonads in mice and voles (Howard, 1927, 1940; Jones, 1949a, b, 1955, 1957; Delost, 1954; Deanesly, 1958; Chitty \& Clarke, 1963; Christian \& Davis, 1964; Jorné-Safriel, 1968; Siuda, 1973; Hirokawa \& Ishikawa, 1975), including the bank vole (Delost \& Delost, 1954; Siuda, 1973). 
The bank vole is a seasonally breeding species (Baker \& Ranson, 1933; Brambell \& Rowlands, 1936) although exceptional winter breeding has been noted (Zejda, 1962; Newson, 1963; Larsson, Hansson \& Nyholm, 1973).

The present investigation was undertaken to study histochemically the possible presence of functional differences in the adrenals and gonads of male bank voles exposed to long or short photoperiods. The somatic growth of the animals in the two different photoperiods was also studied.

\section{Animals}

\section{Materials and Methods}

Male bank voles were from the laboratory colony which originated from animals trapped in the district of Loppi $\left(60^{\circ} 41^{\prime} \mathrm{N}\right.$ and $\left.24^{\circ} 29^{\prime} \mathrm{E}\right)$ in southern Finland. The animals were kept at $20 \cdot 5 \pm 0 \cdot 20^{\circ} \mathrm{C}$ (s.e.m.) in a short (6 h light: $18 \mathrm{~h}$ dark, lights on $08: 00-14: 00 \mathrm{~h})$ or a long (18L:6D, lights on 06:0024:00 h) photoperiod from weaning (18 days of age) until 67 days of age.

The animals were born and reared in a long photoperiod $(18 \mathrm{~L}: 6 \mathrm{D})$ at a room temperature of $21^{\circ} \mathrm{C}$ until the beginning of the experiment. Water, standard laboratory diet (Hankkija, Helsinki, Finland) and apples were always available. Lighting was provided by Osram $40 \mathrm{~W}$ white fluorescent lamps and the mean intensity of light was about $150 \mathrm{~lx}$. The voles were kept in sibling pairs in $32 \times 41 \times 12 \cdot 5$ $\mathrm{cm}$ plastic cages. Each group (S, short photoperiod, and L, long photoperiod) consisted of 20 animals, which were weighed at 1-week intervals. A control group (C) of 20 animals was killed at 18 days of age.

All animals were killed by decapitation between 12:30-14:00 h. The left testis and both adrenal glands were immediately excised and frozen in liquid nitrogen. Cryostat sections cut at $-20^{\circ} \mathrm{C}$ were attached to dry clean coverslips by momentary thawing. The right testis was weighed on a Mettler balance, fixed in Bouin's fluid, embedded in paraffin wax, sectioned at $6 \mu \mathrm{m}$ and stained with PASMayer's haematoxylin (Leblond \& Clermont, 1952). The diameter of 12 seminiferous tubules from each testis was measured by means of a Wild graduated ocular.

\section{Histochemistry}

The lipids were studied by the method of Chiffelle \& Putt (1951), with Fettrot 7B (Ciba, Basel, Switzerland) as the lipid dye. The following enzymes were studied: $3 \alpha-, \Delta^{5}-3 \beta-, 11 \beta-$ and $17 \beta-h y-$ droxysteriod dehydrogenases and NADH- and NADPH-diaphorases. The $\Delta^{5}-3 \beta-, 11 \beta$ - and $17 \beta-$ hydroxysteriod dehydrogenases (HSD) were studied by using essentially the method of Wattenberg (1958) with some minor modifications (Pearse, 1972). Both of the two pyridine nucleotides, NAD and NADP, were used with $3 \alpha-, 11 \beta$ - and $17 \beta-H S D$. Only NAD was used with $\Delta^{5}-3 \beta-H S D$. Polyvinylpryrrolidine (PVP: BASF, Ludwigshafen, West Germany) was added to the incubation media (final concentration $7 \cdot 5 \%$ ) to preserve the mitochondrial morphology and to minimize enzyme diffusion during the incubation procedure (Pearse, 1972). The activity of $3 \alpha-$ HSD was studied by the method of Balogh (1966). The diaphorases were studied with NADH and NADPH as substrates (Scarpelli, Hess \& Pearse, 1958) as described by Pearse (1972). All cryostat sections except those for examination of the lipids were treated with cold acetone $\left(-20^{\circ} \mathrm{C}\right)$ before incubation. Lipid inclusions in the tissues may cause localization artefacts due to formazan lipid adsorbance (Pearse \& Hess, 1961). Control sections were incubated without substrate.

The following substrates were used: dehydroepiandrosterone (3ß-hydroxyandrost-5-en-17-one: Sigma, St Louis, U.S.A.), dehydroepiandrosterone sulphate (3$\beta$-sulphoxy-androst-5-en-17-one: Makor Chemicals, Jerusalem, Israel), testosterone (17 $\beta$-hydroxy-4-androsten-3-one: Sigma), androsterone ( $3 \alpha$-hydroxy-5 $\alpha$-androstan-17-one: Sigma), corticosterone (11 $\beta, 21$-dihydroxy-4-pregnene-

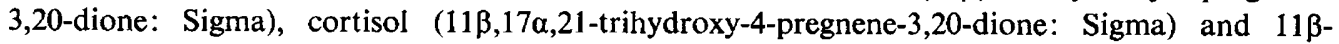
hydroxyandrostenedione (11 -hydroxyandrost-4-ene-3,17-dione: Merck, Darmstadt, Germany). NAD, NADP, NADH and NADPH were purchased from Boehringer (Mannheim, West Germany) and nitrobluetetrazolium from Sigma.

\section{Statistical analysis}

Square root transformations were applied to the data when necessary and significance was assessed by analysis of variance (single-factor ANOVAR). 


\section{Results}

\section{Testicular and body weights}

Group $\mathrm{L}$ animals had significantly $(P<0.001 ; \mathrm{F}=2311 \cdot 40)$ larger right testes $(336 \cdot 70 \pm 7 \cdot 81$ (s.e.m.) $\mathrm{mg}, n=20)$ than those in Group C (37.70 $\pm 1.62 \mathrm{mg}, n=20)$. One individual in Group S had a very large testis $(62 \mathrm{mg})$ and this value was omitted from the mean weight for the group. The mean testis weight of the Group $S$ animals $(8.26 \pm 0.74 \mathrm{mg}, n=19)$ was also significantly less $(P<0.001$; $\mathrm{F}=323 \cdot 19)$ than that of the Group $\mathrm{C}$ animals.

The somatic growth of the animals was also strikingly different in the two groups (Table 1).

Table 1. The somatic growth (changes in the mean \pm s.e.m. body weight) of voles in the two photoperiodic groups

\begin{tabular}{|c|c|c|c|c|c|c|c|}
\hline \multirow[b]{2}{*}{ Group } & \multirow[b]{2}{*}{18} & \multicolumn{6}{|c|}{ Age (days) } \\
\hline & & 25 & 32 & 39 & 46 & 53 & 60 \\
\hline $\begin{array}{c}S \\
(6 L: 18 D)\end{array}$ & $\begin{array}{r}11.33 \\
\pm 0.25\end{array}$ & $\begin{array}{r}15.30 \\
\pm 0.45\end{array}$ & $\begin{array}{r}17.01 \\
\pm 0.39\end{array}$ & $\begin{array}{r}17.49 \\
\pm 0.37\end{array}$ & $\begin{array}{r}17.53 \\
\pm 0.47\end{array}$ & $\begin{array}{r}17.16 \\
\pm 0.58\end{array}$ & $\begin{array}{r}17.88 \\
\pm 0.63\end{array}$ \\
\hline $\begin{array}{c}\mathrm{L} \\
(18 \mathrm{~L}: 6 \mathrm{D})\end{array}$ & $\begin{array}{r}11.18 \\
\pm 0.20\end{array}$ & $\begin{array}{r}15.77 \\
\pm 0.36\end{array}$ & $\begin{array}{c}19.69 \\
\pm 0.45^{*}\end{array}$ & $\begin{array}{c}21.06 \\
\pm 0.47^{*}\end{array}$ & $\begin{array}{c}22.73 \\
\pm 0.48^{*}\end{array}$ & $\begin{array}{c}23.29 \\
\pm 0.51^{*}\end{array}$ & $\begin{array}{r}23.33 \\
\pm 0.61^{*}\end{array}$ \\
\hline
\end{tabular}

* These values were significantly different from those of Group $\mathrm{S}, P<0.001$ (F values of $19 \cdot 96,35 \cdot 03,58 \cdot 26,62 \cdot 52$ and $38 \cdot 51$ respectively).

\section{Histology and histochemistry}

$P A S$-haematoxylin. The animals in Group $L$ had active testes: the seminiferous tubules (diam. $185.05 \pm 2.83 \mu \mathrm{m}$ ) contained spermatogonia, spermatocytes and spermatids in different stages of maturation (Pl. 1, Fig. 2). The Leydig cells between the seminiferous tubules were lightly PAS-positive with large spherical or ovoid nuclei staining lightly with haematoxylin (Pl. 1, Fig. 5):

The Group S animals had regressed testes with small seminiferous tubules (diam. 47.20 $\pm 1 \cdot 39$ $\mu \mathrm{m}$ ), which contained only spermatogonia, usually clustered peripherally, and Sertoli cells, orientated more centrally. The Sertoli cells were elongated with strongly basophilic nuclei, while the spermatogonia had large spherical, lightly basophilic nuclei. Some mitotic figures could be seen in the spermatogonia, but meiotic stages were rarely observed. The elongated Leydig cell nuclei stained darkly with haematoxylin and the cytoplasm was scarce and lacking in PAS-positive material. The interstitial cells had a tendency to form larger clusters between the seminiferous tubules than they did in the active testes. Sometimes the interstitial tissue filled the entire intertubular space (Pl. 1, Fig. 6). The tunica albuginea was thicker in regressed than in active testes (Pl. 1, Figs 4 and 8 ). The endothelium lining the seminiferous tubules formed numerous folds, while in the active testes it was straight and smooth. The lumen of the seminiferous tubules sometimes contained masses of degenerating cells (Pl. 1, Fig. 1).

The testes of the Group $\mathrm{C}$ animals were clearly more active than those of the Group $\mathrm{S}$ animals. The seminiferous tubules were wider $(84.90 \pm 1.75 \mu \mathrm{m})$ and primary spermatocytes in early stages of meiosis and spermatogonia, Sertoli cells were present. No spermatids or mature spermatozoa were observed. The tunica albuginea surrounding the testis was narrow and the endothelium lining the seminiferous tubules was straight. Interstitial cells between the tubules were scarce. The Leydig cells were similar to those seen in active mature testes; the nuclei were, however, smaller and usually more irregular in outline (Pl. 1, Fig. 3).

Lipids. In the testes of Group $\mathrm{L}$ animals lipids were found mainly in the Leydig cells and in the intratubular spaces. The lipid formed fine inclusions. In some interstitial cells a few larger lipid drop- 
lets could be seen. In Group $\mathrm{S}$ animals the interstitium was devoid of lipids, but fine lipid droplets were detected in the seminiferous epithelium (Pl. 1, Figs 7 and 8).

In the sexually active animals (Group $L$ ) the adrenal cortex stained very lightly and was almost devoid of lipid inclusions. The medulla was entirely negative. In Group S animals there was some variation in the amount of lipids in the adrenal cortex, but the main distribution of the lipids was constant. The largest lipid droplets were found in the basal parts of the zona fasciculata. There was quite often a narrow, almost lipid-free juxtamedullary zone (probably the X-zone). Islands of cortical cells with fine lipid granules sometimes occurred in the medulla. The lipid inclusions were quite extensive in some specimens, particularly in the inner zona fasciculata. The zona intermedia and zona glomerulosa had few lipid inclusions (Pl. 2, Fig. 15).

$N A D H$-diaphorase. In the testes of Group L animals the Leydig cells and the sperm fiagella (P1. 2, Fig. 11) showed the most intense enzymic activity: the seminiferous tubules were only moderately active. The control sections were entirely negative. In Group S animals the difference between the interstitial tissue and the seminiferous tubules was much less obvious; the positively reacting interstitial cell groups were larger and more scattered, but the enzymic activity was weaker than in the sexually active animals.

The enzyme distribution in the adrenal cortex of the animals in Group $L$ was even; there was a strong reaction in all cortical layers. The medulla showed a moderate enzymic activity. In the Group $\mathbf{S}$ animals the diaphorase distribution in the cortex was similar to that in Group $L$ animals, but the activity in the zona intermedia and the juxtamedullary zone (which in these animals was quite narrow) was generally weaker (PI. 2, Fig. 14).

NADPH-diaphorase. The distribution of NADPH-diaphorase was similar to that of NADHdiaphorase in the active and regressed testes, although the sperm flagella were inactive (Pl. 2, Fig. 12 ), the activity in Group $L$ testes was slightly weaker, the reaction in the interstitial cells of the regressed testes was slightly stronger (PI. 2, Fig. 10).

The NADPH-diaphorase activity in the adrenal cortex was also similar to that of NADHdiaphorase, although generally slightly weaker, except in the subcapsular glomerular cells which gave a stronger reaction.

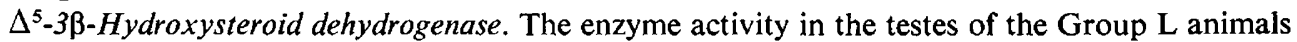
was mainly confined to the interstitial cells, which showed quite a strong reaction (Pl. 2, Fig. 9). Trace amounts of formazan were also detectable in the seminiferous tubules, but this activity was most probably due to alcohol dehydrogenase activity, because similar amounts of formazan were observed

\section{EXPLANATION OF PLATE 1}

Group $\mathrm{L}=67$-day-old voles kept in a long photoperiod, 18L:6D; Groups $S=67$-day-old voles kept in a short photoperiod, $6 \mathrm{~L}: 18 \mathrm{D}$; Group $\mathrm{C}=$ voles kept in a long photoperiod, $18 \mathrm{~L}: 6 \mathrm{D}$, and killed at 18 days of age.

Fig. 1. Cells in different stages of degeneration in the intratubular spaces (arrows) of the regressed testis of a bank vole in Group S. PAS-haematoxylin.

Fig. 2. Seminiferous tubules in a Group L vole showing normal sexual activity. PAS-haematoxylin.

Fig. 3. Testis of a Group $\mathrm{C}$ animal, showing early spermatogenesis. $\mathrm{SP}=$ spermatogonia ; $\mathrm{SC}=$ spermatocytes; $\mathrm{T}=$ tunica albuginea. PAS-haematoxylin.

Fig. 4. Testis typical of a Group $S$ vole. Note the thick tunica albuginea (T). $S P=$ spermatogonia; $S=$ Sertoli cell. PAS-haematoxylin.

Fig. 5. Leydig cells (L) in the testis of a Group L vole. $S=$ Sertoli cell. PAS-haematoxylin.

Fig. 6. Leydig cells (L) in a Group $S$ vole. $S=$ Sertoli cells; $S P=$ spermatogonia. PAS-haematoxylin.

Fig. 7. The distribution of lipids in the testis of a sexually active vole (Group L). L= Leydig cells with lipid inclusions; IL = intratubular lipid. Fettrot 7B-haematoxylin.

Fig. 8. The distribution of lipids in a Group $S$ testis: the lipid content is very poor. $T=$ tunica albuginea. Fettrot 7B-haematoxylin. 

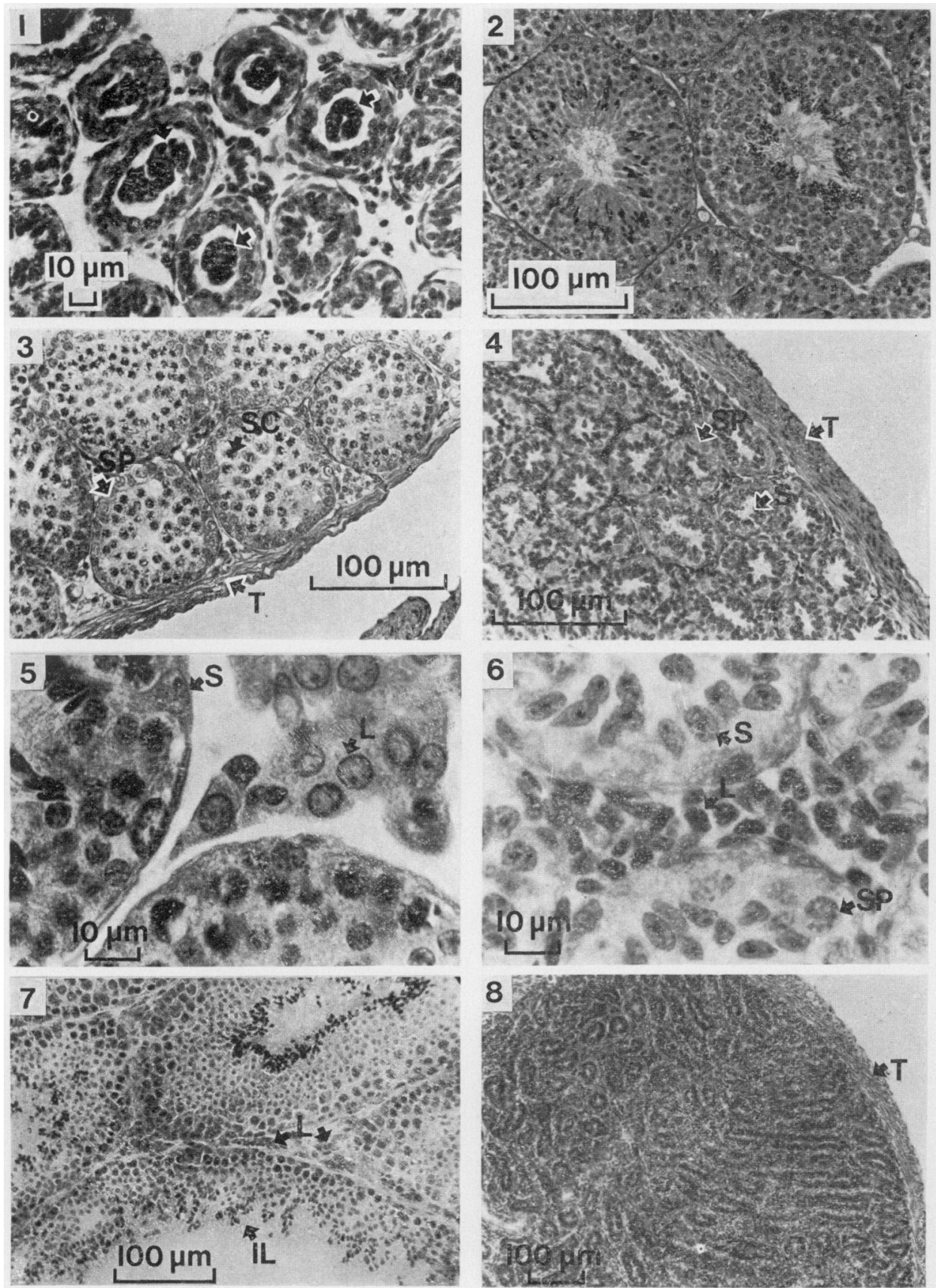

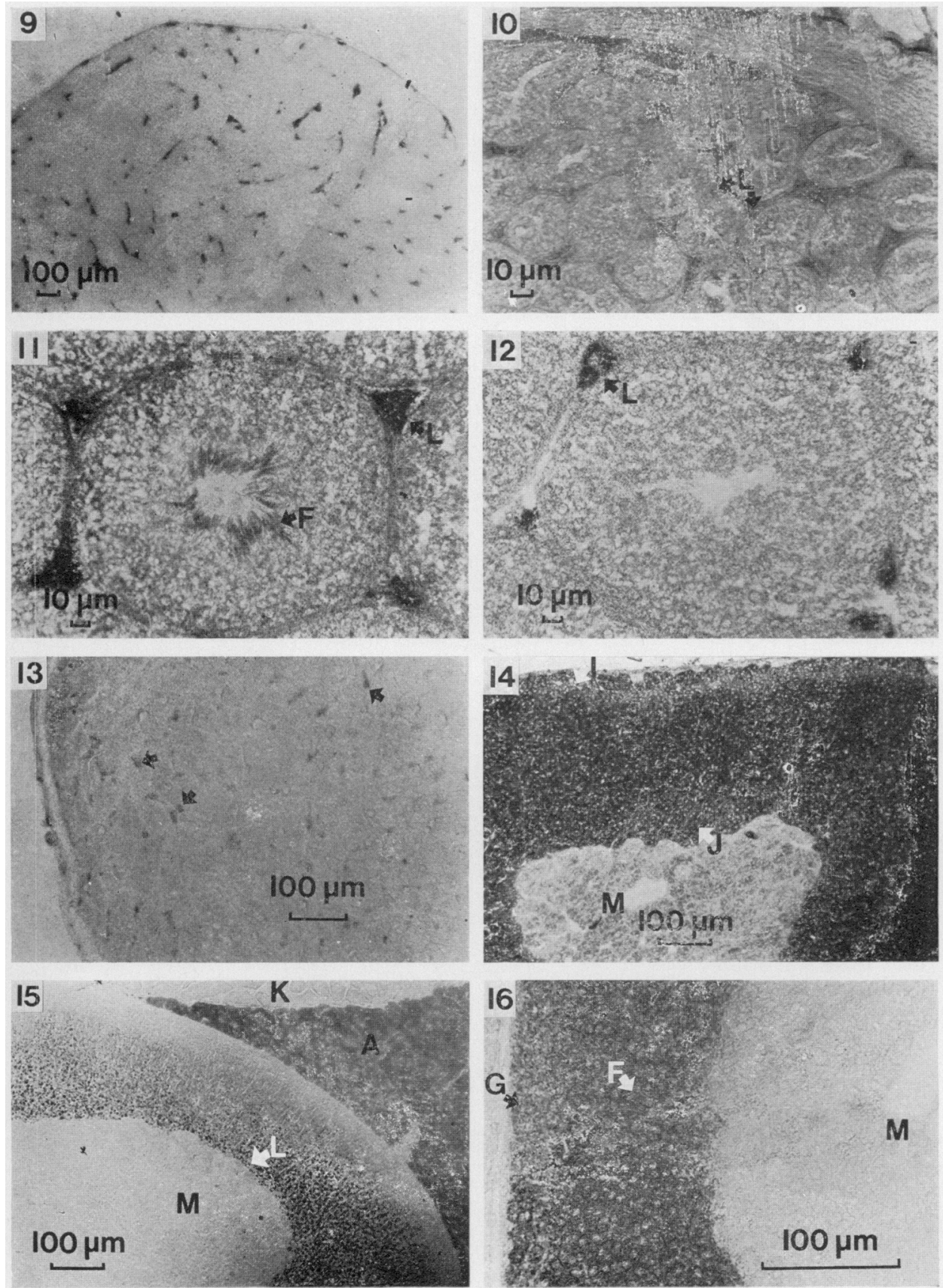
in control sections. In the Group $S$ animals the interstitial cells gave a very faint reaction, while the seminiferous tubules were virtually devoid of formazan. When dehydroepiandrosterone sulphate was used as a substrate, no enzyme activity was observed in either group.

In Group $\mathrm{L}$ animals the whole adrenal cortex showed strong enzyme activity, although that in the zona glomerulosa was often weaker than in the other cortical layers. The medulla was inactive (Pl. 2, Fig. 16). The overall intensity of the reaction (the formazan intensity) was, however, weaker than with the diaphorases. A similar enzyme distribution was seen in the Group S animals. The formazan present in the zona glomerulosa was generally reddish monoformazan, while the formazan in the other cortical layers was blue diformazan. There was in many cases a very narrow juxtamedullary zone devoid of enzyme activity. Dehydroepiandrosterone sulphate failed to give positive results in the adrenals of either group.

$3 \alpha$-Hydroxysteroid dehydrogenase. When NAD was used as a coenzyme, the Leydig cells of the active testes showed an intense enzyme activity. The reaction was considerably weaker with NADP. In the Group S animals a very weak enzyme activity with NAD was detected in the interstitial tissue (Pl. 2, Fig. 13). In both groups, the adrenal cortex showed an overall weak reaction with the strongest activity in the zona glomerulosa.

$11 \beta$-Hydroxysteroid dehydrogenase. With all substrates and both pyridine nucleotides the testes of Group $\mathrm{L}$ and Group $\mathrm{S}$ animals were devoid of enzyme activity. In both groups the adrenal cortex showed sparse formazan deposits. 11ß-Hydroxyandrostenedione was not used as a substrate when studying $11 \beta$-HSD activity in Group S animals.

$17 \beta-H y d r o x y$ steroid dehydrogenase. With NADP, a moderate enzyme activity, localized mainly in the interstitial tissue of the testis, was noted in the Group $L$ animals, but there was no enzyme activity with either of the pyridine nucleotides in the testes of the Group S animals. The adrenals showed a weak cortical activity in both groups.

\section{Discussion}

The present results show that short photoperiods have an inhibitory effect on the somatic growth and sexual maturation of male bank voles. It is also evident that a short photoperiod of $6 \mathrm{~L}: 18 \mathrm{D}$ not only arrested the normal activation of the gonads, but also exerted a strong inhibitory influence on the

\section{EXPLANATION OF PLATE 2}

Fig.9. The distribution of $3 \beta$-hydroxysteroid dehydrogenase in the testis of a Group L vole. Only the Leydig cells show strong activity; the seminiferous tubules are inactive. The distribution of $3 \alpha-$ and $17 \beta$-hydroxysteroid dehydrogenases are identical, activity being confined to the Leydig cells only.

Fig. 10. The NADPH-diaphorase distribution in the testis of a Group $\mathbf{S}$ vole. $\mathbf{L}=$ moderately reacting Leydig cells.

Fig. 11. NADH-diaphorase activity in a Group L testis. Note the strong reaction in the sperm flagella (F). $\mathbf{L}=$ Leydig cells.

Fig. 12. NADPH-diaphorase activity in a Group $L$ testis. There is no reaction in the flagella and the overall intensity is weaker than in Fig. 11. $\mathrm{L}=$ Leydig cells.

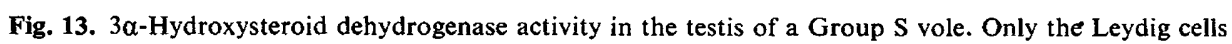
(arrows) show a weak reaction. The $3 \alpha$-and $3 \beta$-hydroxysteroid dehydrogenase distributions in the testes of Group S voles were identical.

Fig. 14. NADH-diaphorase distribution in the adrenals of a Group S bank vole. Note the slightly weaker reaction in the zona intermedia (I) and the juxtamedullary zone (J). $M=$ medulla.

Fig. 15. The distribution of lipids in the adrenal cortex of a Group S vole. The largest inclusions are situated in the basal zona fasciculata (arrows). $\mathbf{M}=$ medulla; $\mathbf{L}=$ lipid inclusion; $\mathbf{A}=$ adipose tissue; $\mathrm{K}=\mathbf{k i d n e y}$.

Fig. 16. The $3 \beta$-hydroxysteroid dehydrogenase distribution in the adrenal cortex of the sexually active bank vole (Group $L$ ). Note that the activity in the zona glomerulosa $(G)$ is weaker than in the other cortical layers. $\mathbf{F}=$ zona fasciculata $\mathbf{M}=$ medulla. 
function of the seminiferous epithelium and the interstitial tissue, leading to regression of the testes to a non-spermatogenic state. The histological appearance of the regressed testes resembled closely that seen in immature bank voles caught in the field in winter (Rowlands, 1936). An inhibitory effect of short photoperiods on gonadal function has also been noted in other species of voles (Baker \& Ranson, 1932; Pinter \& Negus, 1965; Clarke \& Kennedy, 1967). However, contradictory results have also been obtained (Cowan \& Arsenault, 1954; Marshall \& Wilkinson, 1956; Roth, 1974; Delost \& Delost, 1975). This lack of agreement may reflect genetic intra-and inter-specific variation in the susceptibility of voles to short photoperiods or perhaps to differences in the experimental design and the photoperiodic 'history' of the animals used. It is not known whether this inhibitory effect in bank voles is permanent or whether a spontaneous activation of the testes of animals kept continuously in short photoperiods would eventually occur. Activation of the testes of wild bank voles occurs in England during January and February (Rowlands, 1936) but this could be spontaneous or elicited by increasing daylength.

In the hamster, in which photoperiodic effects on gonadal function have been much studied, the attainment of sexual maturity is independent of photoperiod length (Stetson, Matt \& WatsonWhitmyre, 1976), although sexually mature animals undergo gonadal regression when kept in a short photoperiod (Reiter, Sorrentino \& Hoffman, 1970). An endogenous circadian rhythm of photosensitivity seems to exist in the hamster (Elliot, Stetson \& Menaker, 1972) and the gonads will become functionally regressed if the sensitive period does not coincide with a light period. Such an endogenous circadian rhythm has also been suggested for Microtus arvalis and $M$. agrestis (Martinet, 1963; Breed \& Clarke, 1970). The inhibitory effect of short photoperiod on gonadal function in the hamster is not permanent. After 20-21 weeks in a short photoperiod, spontaneous activation of the gonads will occur (Reiter, 1969). Hamster testes rendered sexually regressed by short photoperiods and then activated by long photoperiods are refractory to the inhibitory effects of short photoperiods and will respond to short photoperiods only after being exposed to long photoperiods for 10-20 weeks (Reiter, 1972). If it is postulated that a similar period of photorefractoriness exists in voles and that spontaneous activation of the gonads would eventually occur, then animals caught in the field at different times of the year would react differently to short photoperiods. The photoperiod may thus play a significant role in the timing of sexual activity in seasonally breeding rodents, but other factors, such as the quality and quantity of the food supply, are probably also involved (Pinter \& Negus, 1965), particularly in the timing of the spontaneous activation of the gonads in late winter (Zejda, 1962; Kaikusalo, 1972; Roth, 1974; Delost \& Delost, 1975).

The absence of histochemically detectable lipids in the interstitial cells of sexually regressed animals in the winter has been described in several seasonally breeding species (Marshall \& Wilkinson, 1956; Lofts, 1960; Clarke \& Forsyth, 1964). Between February and May, when gonadal activation occurs, there is a steady accumulation of lipids and cholesterol in the interstitium and a progressive depletion after mating (Marshall \& Wilkinson, 1956; Lofts, 1960).

The absence of histochemically detectable lipids in the interstitial cells of the regressed testes of voles is probably a sign of diminished cholesterol and steroid biosynthesis. The marked differences in the intensity of NADH- and NADPH-diaphorase reactions (especially NADH-diaphorase) in the interstitial cells of the active and regressed testes suggests quantitative changes in some functional activity possibly associated with the lipid and/or oxidative metabolism. The interpretation of the diaphorase reactions constitutes a problem, since the enzymes have not been precisely identified (Hatefi, 1963). The weak diaphorase reactions (especially NADH-diaphorase) in the Leydig cells of some regressed testes make it more difficult to interpret the other histochemical results. Because no exogenous hydrogen carrier such as phenazine methosulphate (PMS) was applied to eliminate diaphorase dependence, the final reduction of nitrobluetetrazolium to the corresponding diformazan was ultimately dependent on the diaphorase activities in the tissue. PMS was not used because of the many histochemical difficulties involved (Hashimoto, Kaluza \& Burstone, 1964; Pearse, 1972). The absence of histochemically demonstrable $17 \beta$-HSD activity in the regressed testes and the marked differences in intensity of the $\Delta^{5}-\beta 3-H S D$ activity in the active and regressed testes probably reflect a diminished steroid and androgen synthesis in the testes related to a decline in the secretion of hypo- 
physial gonadotrophins (Levy, Deane \& Rubin, 1959; Martinet \& Meunier, 1975; Tamarkin, Hutchison \& Goldman, 1976).

In the present study $17 \beta-H S D$ was found to be NAD-linked. Biochemically this enzyme is known to be NADP-linked in the testis (Eik-Nes, 1975), but histochemically it is generally considered to be NADP- and NAD-linked (Baillie, Ferguson \& Hart, 1966). Dehydroepiandrosterone sulphate as a substrate gave negative results in all the testes. In the mouse it is known to give a positive reaction in the seminiferous tubules, coinciding with the development of mature spermatozoa (Baillie \& Griffiths, 1965), and $3 \beta$-sulphoxysteroids give a positive reaction in human interstitial cells, being particularly intense in the Leydig cells of cryptorchid testes (Baillie \& Mack, 1966). However, the precise role of the steroid sulphates in steroid hormone synthesis remains obscure. In the present study $3 \alpha-H S D$, which reversibly oxidizes androsterone ( $5 \alpha$-androstan-3 $\alpha$-ol-17-one) to the corresponding ketone (androstanedione), was predominantly NAD-linked. When NADP was used as a coenzyme, the reaction was considerably weaker, contrasting with the results of Balogh (1966), who obtained identical results with both pyridine nucleotides in the rat, The weak enzyme activity observed in the regressed testes of voles may indicate a decline in the intermediary metabolism of $C_{19}$ steroids.

The activity of $11 \beta-H S D$ has been demonstrated histochemically in human and murine Leydig cells (Baillie, Ferguson, Calman \& Hart, 1965): the most suitable substrates are 11ß-hydroxyprogesterone and 11 $\beta$-hydroxyandrostenedione (Baillie et al., 1966). The enzyme seems to be lacking in the stallion testis (Savard \& Goldzieher, 1960). Our negative results may be an indication of the substrate specificity of testicular $11 \beta$-HSD in the bank vole or indicate the absence of such a histochemically demonstrable enzyme in the testis of this species.

The striking difference in histochemically demonstrable adrenocortical lipids between the inactive and sexually active voles is difficult to interpret. The relation of lipids to the synthesis and secretion of corticosteroids varies with the species. In some the normal secretion and synthesis of adrenocortical steroids is not accompanied by the occurrence of lipid droplets in the cortex (Nicander, 1952; Knigge, 1954; Deane \& Lyman, 1954) and this seems to be the case in sexually active male bank voles. In rats, ACTH stimulation causes depletion of adrenocortical lipids (Sayers \& Sayers, 1948; Ducommun \& Mach, 1949). Excessive ACTH stimulation may, however, lead to an accumulation of large droplets of non-cholesterol lipids in the basal zona fasciculata and the zona reticularis and the disappearance of the zona glomerulosa (Baker, 1952). The pineal gland may exert an inhibitory influence on the function of the adrenal cortex (Kinson et al., 1967, 1968; Motta, Schiaffini, Piva \& Martini, 1971; Vaughan et al., 1972), and because the pineal is functionally active in animals kept in short photoperiods (Wurtman, Axelrod \& Kelly, 1968), the accumulation of lipid droplets in the basal zona fasciculata is interpreted as evidence of a decreased corticosteroid synthesis and/or secretion from the adrenal gland.

The length of the photoperiod had no significant effect on the intensity or distribution of the diaphorases or $3 \alpha-, 11 \beta$ - and $17 \beta$-HSD in the adrenal cortex of male bank voles. The negative or very weak reactions obtained with $3 \alpha-, 11 \beta$ - and $17 \beta-H S D$ are in accordance with the histochemical results obtained with other species (Baillie et al., 1966). The narrow juxtamedullary zone, which was devoid of $\Delta^{5}-3 \beta$-HSD activity, in the adrenals of the sexually inactive animals is probably the transient $X$ zone (Delost, 1952; Delost \& Delost, 1954; Siuda, 1973), as found in sexually regressed male common voles $(M$. arvalis). The persistence of the X-zone is probably due to the diminished androgen secretion by the regressed testes.

I thank Professor Henrik Wallgren, Head of the Division of Physiology, for his interest and encouragement during the course of my work; Mrs Riitta Suoranta for technical assistance; Mr Heikki Henttonen for help with the statistics; and my wife, Mrs Sinikka Tähkä, for helping to prepare the manuscript. 


\section{References}

Baillie, A.H. \& Griffiths, K. (1965) Further observations on $3 \beta$-hydroxysteroid dehydrogenase activity in the mouse Leydig cell. J. Endocr. 31, 207-215.

BaIllie, A.H. \& MACK, W.S. (1966) Hydroxysteroid dehydrogenases in normal and abnormal human testes. J. Endocr. 35, 239-248.

Baillie, A.H., Ferguson, M.M., Calman, K.C. \& HART, D.MCK. (1965) Histochemical demonstration of $11 \beta$-hydroxysteroid dehydrogenase. J. Endocr. 33, 119-125.

Baillie, A.H., Ferguson, M.M. \& Hart, D.McK. (Eds) (1966) Developments in Steroid Histochemistry, 1st edn. Academic Press, London.

BAKER, B.L. (1952) A comparison of the histological changes induced by experimental hyperadrenocorticalism and inanition. Recent Prog. Horm. Res. 7, 331-373.

BAKER, J.R. \& RANSON, R.M. (1932) Factors affecting the breeding of the field mouse (Microtus agrestis). Part 1. Light. Proc. $R$. Soc. B 110, 313-322.

BAKER, J.R. \& RANSON, R.M. (1933) Factors affecting the breeding of the field mouse (Microtus agrestis). Part III. Locality. Proc. $R$. Soc. B 113, 486-495.

BALOGH, K., JR (1966) Histochemical demonstration of $3 \alpha$-hydroxysteroid dehydrogeanse activity. J. Histochem. Cytochem. 14, 77-83.

Berndtson, W.E. \& Desjardins, C. (1974) Circulating LH and FSH levels and testicular function in hamster during light deprivation and subsequent photoperiodic stimulation. Endocrinology 95, 195-205.

BRAmbell, F.W. \& Rowlands, I.W. (1936) Reproduction in the bank vole (Evotomys glareolus, Schreber). I. The oestrous cycle of the female. Phil. Trans. $R$. Soc. Ser. B 226, 71-97.

Breed, W.G. \& Clarke, J.R. (1970) Effect of photoperiod on ovarian function in the vole, Microtus agrestis. J. Reprod. Fert. 23, 189-192.

Charlton, H.M., Grocock, C.A. \& Ostberg, A. (1976) The effects of pinealectomy and superior cervical ganglionectomy on the testis of the vole. J. Reprod. Fert. 48, 377-379.

Chiffelle, T.I. \& Putt, A.F. (1951) Propylene and ethylene glycol as solvents for Sudan IV and Sudan Black B. Stain Technol. 26, 51-56.

ChitTy, H. \& ClARKe, J.R. (1963) The growth of the adrenal gland of laboratory and field voles, and changes in it during pregnancy. Can. J. Zool. 41, 1025-1034.

Christian, J.J. \& Davis, E.D. (1964) Endocrines, behaviour and population. Science, N.Y. 146, 15501560.

Clarke, J.R. \& Farrar, G. (1975) The effect of pinealectomy and chemical sympathectomy upon gonadal function in the vole, Microtus agrestis. Acta endocr., Copenh., Suppl. 199, 248, Abstr.

Clarke, J.R. \& Forsyth, I.A. (1964) Seasonal changes in the gonads and accessory reproductive organs of the vole (Microtus agrestis). Gen. comp. Endocr. 4, 233-242.

Clarke, J.R. \& Kennedy, J.P. (1967) Effect of light and temperature upon gonad activity in the vole (Microtus agrestis). Gen. comp. Endocr. 8, 474-488.
Cowan, I. MCT. \& Arsenault, M.G. (1954) Reproduction and growth in the creeping vole (Microtus oregoni serpens Merriam). Can. J. Zool. 23, 198-208.

DEANE, H.W. \& Lyman, C.P. (1954) Body temperature, thyroid and adrenal cortex of hamster during cold exposure and hibernation, with comparisons to rats. Endocrinology 55, 300-315.

DeANesly, R. (1958) Secretion of androgens by the adrenal cortex of the mouse. Nature, Lond. 182, 262-263.

Delost, P. (1952) Le cortex surrénal du campagnol des champs (Microtus arvalis $P$.) et ses modifications après castration. C. r. Séanc. Soc. Biol. 146, 27-31.

Delost, P. (1954) Action involutive de la cortisone sur la zone $\mathrm{X}$ surrénalienne du campagnol des champs (Microtus arvalis P.). C. r. Séanc. Soc. Biol. 148, 1161-1163.

Delost, P. \& Delost, H. (1954) Existence d'une zone X surrénalienne chez le campagnol roussâtre (Clethrionomys glareolus S.). C. r. Séanc. Soc. Biol. 148, 1788-1793.

Delost, P. \& Delost, H. (1975) Déterminisme du cycle sexuel circannuel du campagnol des champs de sexe mâle. J. Physiol., Paris 70, 521-532.

Ducommun, P. \& MACH, R.S. (1949) Effet de l'hormone adrenocorticotrope sur la morphologie du cortex surrénalien, son contenu en acide ascorbique et en esters de cholestérol chez le rat normal. Acta endocr., Copenh. 3, 17-26.

EIK-Nes, K.B. (1975) Biosynthesis and secretion of testicular steroids. In Handbook of Physiology 2nd edn, Vol. V, sec. 7, pp. 95-115. Eds R. O. Greep, E. B. Astwood, D. W. Hamilton \& S. Geiger. American Physiological Society, Washington, D.C.

Elliot, J.A., Stetson, M.H. \& Menaker, M. (1972) Regulation of testis function in golden hamsters: a circadian clock measures photoperiodic time. Science, N. Y. 178, 771-773.

Hashimoto, T., Kaluza, J.S. \& Burstone, M.S. (1964) The effect of menadione and phenazine methosulphate on the tetrazolium reduction system under histochemical conditions. J. Histochem. Cytochem. 12, 797-804.

HATEFI, Y. (1963) The pyridine nucleotide--cytochrome c reductases. In The Enzymes, Vol. 7, pp. 495-515. Eds P. D. Boyer, H. Lardy \& K. Myrbäck. Academic Press, New York.

Herbert, J. (1971) The role of the pineal gland in the control by light of the reproductive cycle of the ferret In The Pineal Gland, pp. 303-327. Eds G. E. W. Wolstenholme \& J. Knight. Churchill Livingstone, Edinburgh.

Hirokawa, N. \& IshiKawa, H. (1975) Electron microscopic observations on the castration-induced $X$ zone in the adrenal cortex of male mice. Cell Tiss. Res. 162, 119-130.

Hoffman, K. (1973) The influence of photoperiod and melatonin on testis size, body weight and pelage colour in the dzungarian hamster (Phodopus sungorus). J. comp. Physiol. 85, 267-282. 
Hoffman, R.A. \& ReITer, R.J. (1965) Pineal gland: influence on gonads of male hamsters. Science, N. $Y$. 141, 1069-1611.

Howard, E. (1927) A transitory zone in the adrenal cortex which shows age and sex relationships. $A m . J$. Anat. 40, 251-293.

Howard, E. (1940) Regarding the effects of desoxycorticosterone and of testosterone on the adrenal X-zone. Anat. Rec. 77, 181-188.

JoNES, I.C. (1949a) The action of testosterone on the adrenal cortex of the hypophystectomized, prepubertally castrated male mouse. Endocrinology 44, 427-438.

JONES, I.C. (1949b) The relationship of the mouse adrenal cortex to the pituitary. Endocrinology 45, 514-536.

JONES, I.C. (1955) Role of the adrenal cortex in reproduction. Br. med. Bull. 11, 156-160.

Jones, I.C. (1957) The Adrenal Cortex, 1st edn. Cambridge University Press.

JORNÉ-SAFRIEL, O. (1968) Some factors affecting the adrenal juxtamedullary zone in the vole (Microtus agrestis) and bank vole (Clethrionomys glareolus). D.Phil. thesis, Oxford University.

Kaikusalo, A. (1972) Population turnover and wintering of the bank vole, Clethrionomys glareolus (Schreb.), in southern and central Finland. Ann. Zool. Fenn. 9, 219-224.

Kinson, G.A., Wahid, A.K. \& Singer, B. (1967) Effect of chronic pinealectomy on adrenocortical hormone secretion rates in normal and hypertensive rats. Gen. comp. Endocr. 8, 445-454.

Kinson, G.A., Singer, B. \& Grant, L. (1968) Adrenocortical hormone secretion at various time intervals after pinealectomy in the rat. Gen. comp. Endocr. 10, 447-449.

Kitay, J.I. \& Atlschule, M.D. (1954) The Pineal Gland, 1st edn, p. 48. Harvard University Press, Cambridge, Massachusetts.

KNIGGE, K.M. (1954) The effect of acute starvation on the adrenal cortex of the hamster. Anat. Rec. 120, $555-581$.

Larsson, T.B., Hansson, L. \& NYholm, E. (1973) Winter reproduction in small rodents in Sweden. Oikos 24, 475-476.

Leblond, C.P. \& Clermont, Y. (1952) Spermiogenesis of rat, mouse, hamster and guinea pig as revealed by the acid-fuchsin sulfurous acid technique. $A m . J$. Anat. 90, 167-215.

LECYK, M. (1962) Dependence of breeding in the field vole, Microtus arvalis (Pall.) on light intensity and wavelength. Zoologica Pol. 12, 255-268.

Levy, H., Deane, H.W. \& Rubin, B.L. (1959) Visualizatio of steroid-3 $\beta$-ol-dehydrogenase activity in the tissues of intact and hypophysectomized rats. Endocrinology 65, 932-943.

LoFTs, B. (1960) Cyclical changes in the distribution of the testis lipids of a seasonal mammal (Talpa europaea). Q. Jl microsc. Sci. 101, 199-205.

Marshall, A.J. \& Wilkinson, O. (1956) Reproduction in the Orkney vole (Microtus orcadensis) under sixhour daylength and other conditions. Proc. zool. Soc. Lond. 126, 391-395.

Martinet, L. (1963) Establissement de la spermatogenèse chez le campagnol des champs (Microtus arvalis) en fonction de la durée quotidienne d'éclairement. Annls Biol. anim. Biochim. Biophys. 3, 343-352.

Martinet, L. \& Meunier, M. (1975) Plasma and pituitary levels of $\mathrm{LH}$ in field voles reared under two different photoperiods. J. Physiol., Paris 70, 539-547.

MCCarthy, R. (1975) Onychomys torridus. Mamm. Species 59, 1-5.

Motta, M., Schiaffini, O., Piva, F. \& Martini, L. (1971) Pineal principles and the control of adrenocorticotropin secretion. In The Pineal Gland, pp. 279301. Eds G. E. W. Wolstenhlome \& J. Knight. Churchill Livingstone, Edinburgh.

Newson, R. (1963) Differences in numbers, reproduction and survival between two neighboring populations of bank voles (Clethrionomys glareolus). Ecology 44, 110-120.

Nicander, L. (1952) Histological and histochemical studies on the adrenal cortex of domestic and laboratory animals. Acta anat., Suppl. 16, 1-88.

Pearse, A.G.E. (1972) Histochemistry. Theoretical and Applied, 3rd edn, pp. 841-961. Churchill Livingstone, Edinburgh,

Pearse, A.G.E. \& Hess, R. (1961) Substantivity and other factors responsible for formazan patterns in dehydrogenase histochemistry. Experientia 17, 136141.

Pinter, A.J. \& Negus, N.C. (1965) Effects of nutrition and photoperiod on reproductive physiology of Microtus montanus. Am. J. Physiol. 208, 633-638.

ReIter, R.J. (1969) Pineal function in long term blinded male and female golden hamsters. Gen. comp. Endocr. 12, 460-468.

REITER, R.J. (1972) Evidence for refractoriness of the pituitary-gonadal axis to the pineal gland in golden hamsters and its possible implications in annual reproduction rhythms. Anat. Rec. 173, 365-372.

ReIter, R.J. (1973) Pineal control of a seasonal reproductive rhythm of male golden hamsters exposed to natural day-length and temperature. Endocrinology 92, 423-430.

Reiter, R.J., Sorrentino, S., JR \& Hoffman, R.A. (1970) Daily photoperiodic conditions and pineal antigonadal function in male hamsters. Int. J. Fert. $15,163-170$.

RoTH, R.R. (1974) The effect of temperature and light combinations upon the gonads of male red-backed voles. Biol. Reprod. 10, 309-314.

Rowlands, I.W. (1936) Reproduction in the bank vole (Evotomys glareolus, Schreber). I. Seasonal changes in the reproductive organs of the male. Phil. Trans. $R$. Soc. Ser. B 226, 99-120.

Savard, K. \& Goldzieher, J.W. (1960) Biosynthesis of steroids in stallion testis tissue. Endocrinologv 66, 617-624.

SAYERS, G. \& SAYERS, M.A. (1948) The pituitary-adrenal system. Recent Prog. Horm. Res. 2, 81-116.

Scarpelli, D.G., Hess, R. \& Pearse, A.G.E. (1958) The cytochemical localization of oxidative enzymes. I. Diphosphopyridine nucleotide diaphorase and triphosphopyridine nucleotide diaphorase. J. biophys. biochem. Cytol. 4, 747-760.

SIUDA, S. (1973) The occurrence of X-zone in the adrenal glands of two rodent species. Acta theriol. 18, 471479. 
Stetson, M.H., Matt, K.S. \& Watson-WhitMyre, M. (1976) Photoperiodism and reproduction in golden hamsters: circadian organization and the termination of photorefractoriness. Biol. Reprod. 14, 531-537.

Tamarkin, L., Hutchinson, J.S. \& Goldman, B.D. (1976) Regulation of serum gonadotrophins by photoperiod and testicular hormone in the Syrian hamster. Endocrinology 99, 1528-1533.

Thibault, C., Courot, M., Martinet, L., Mauléon P., du Mesnil du Buisson, F., Ortavant, R., Pelletier, J. \& SignoRET, J.P. (1966) Regulation of breeding season and estrous cycles by light and external stimuli in some mammals. J. Anim. Sci. 25, Suppl. pp. 119-142.

TUReK, F.W., Elliot, J.A., Alvis, J.P. \& Menaker, M. (1975) The interaction of castration and photoperiod in the regulation of hypophyseal and serum gonadotropin levels in male golden hamsters. Endocrinology 96, 854-860.
Vaughan, M.K., Vaughan, G.M., Reiter, R.J. \& BENSON, B. (1972) Effect of melatonin and other pineal indoles on adrenal enlargement produced in male and female mice by pinealectomy, unilateral adrenalectomy, castration and cold stress. Neuroendocrinology 10, 139-154.

WATtenBerg, L.W. (1958) Microscopic histochemical demonstration of steroid- $3 \beta$-ol dehydrogenase in tissue sections. J. Histochem. Cytochem. 6, 225-232.

Wurtman, R.J., AXelrod, J. \& Kelly, D.E. (1968) Light, the pineal and biological rhythms. In The Pineal, 1st edn, Chapter 4, pp. 107-143. Academic Press, New York.

ZEJDA, J. (1962) Winter breeding in the bank vole, Clethrionomys glareolus Schreb. Zool. Listy 11, 309321.

Received 26 October 1977 